\title{
SUPPLEMENTATION OF CALCIUM AND SELENIUM AGAINST CADMIUM INDUCED BIOACCUMULATION IN SELECTED TISSUES OF FRESH WATER FISH, OREOCHROMIS MOSSAMBICUS
}

\author{
OBAIAH JAMAKALA \\ Division of Environmental Toxicology and Animal Physiology, Department of Zoology, Sri Venkateswara University, Tirupati 517502 A. P. India \\ Email: obaiah.j@gmail.com
}

Received: 05 Oct 2018 Revised and Accepted: 28 Nov 2018

\begin{abstract}
Objective: Cadmium (Cd) is one of the most hazardous heavy metals in aquatic environments and could threaten aquatic organisms including fish The present study was carried out to know the protective effects of calcium (Ca) and selenium (Se) in reducing the Cd bioaccumulation in selected
\end{abstract} tissues of fresh water fish, Oreochromis mossambicus.

Methods: The fresh water fish, Oreochromis mossambicus (Tilapia) was brought from the local ponds and were allowed for acclimatization to the laboratory conditions. After acclimatization, fish were exposed to sublethal concentration of $\mathrm{Cd}\left(1 / 10^{\text {th }}\right.$ of $\mathrm{LC}$ 50/48h, i.e., $\left.5 \mathrm{ppm}\right)$ for 7,15 and $30 \mathrm{~d}$ (d) period. 15d Cd-exposed fish were divided into three groups. The first group of fish were subjected to Ca (1 ppm) supplementation, second group received only Se (1 ppm) supplement and third group of fish were supplemented with the combination of both Ca and Se at the above said doses and observed for 7, 15 and 30d time periods. After specific time intervals, liver, kidney, gill and intestine tissues were isolated and used for Cd bioaccumulation studies.

Results: $\mathrm{Cd}$ concentration levels significantly $(\mathrm{P}<0.05)$ increased in the test tissues with increased period of exposure. Maximum Cd accumulation was found in $30 \mathrm{~d}$ Cd-exposed fish kidney tissue $(22.611 \pm 0.676 \mu \mathrm{g} / \mathrm{gm}$ wet wt. of the tissue). However, after supplementing with Ca and/or Se, there was a significant reversal in the levels of $\mathrm{Cd}$ concentration in all the test tissues. Maximum reduction was observed under Ca alone supplementation.

Conclusion: The present study clearly reveals that individual supplementation of Ca tends to detoxify the Cd body burden in the test tissues than the other modes of supplementation.

Keywords: Cadmium, Bioaccumulation, Supplementation, Fish

(C) 2019 The Authors. Published by Innovare Academic Sciences Pvt Ltd. This is an open access article under the CC BY license (http://creativecommons.org/licenses/by/4.0/) DOI: http://dx.doi.org/10.22159/ijpps.2019v11i1.30167

\section{INTRODUCTION}

Metal pollution is one of the most dangerous consequences of industrial activities to the aquatic environment [1]. Because of their persistent nature and slow elimination from environmental compartments, metals are the largest and most widespread groups of contaminants [2]. The diverse deleterious health effect upon exposure to toxic heavy metals such as cadmium $(\mathrm{Cd})$, lead $(\mathrm{Pb})$ and mercury $(\mathrm{Hg})$, etc. in the environment is a matter of serious concern and a global issue. Heavy metals accumulate in the tissues of aquatic animals and may become toxic when accumulation reaches a substantially high level. Studies carried out with different fish species have revealed that non-essential metals can produce toxic effects in fish by disturbing physiological activities [3], biochemical processes [4], reproduction and growth [5].

Cd was readily bioaccumulated and bioconcentrates in aquatic organisms. Tissue Cd concentrations build up at the site of exposure, gills in a waterborne exposure or gastrointestinal tract in a dietborne exposure and are transferred via the circulation to other tissues. $\mathrm{Cd}$ accumulates in nearly all tissues and organs with liver, kidney, and gill reaching relatively high levels. Available reports indicate that the kidney, liver, and gills were the critical targets for $\mathrm{Cd}$ in fishes [6-8] in which they have been reported to cause significant metabolic, biochemical and physiological effects. The bioaccumulation of heavy metals, biochemical, pathological and antioxidant alterations induced by different heavy metals and organic compounds has been studied by several investigators in the different tissues of rats and fish [9-15]

Despite many years of research, we are still far from effective treatment of heavy metal poisoning. The main therapeutic option for metal poisoning relies in chelation therapy. Chelating agents are capable of linking together metal ions to form complex structures which can be easily excreted from the body. We have reported here on the interactions between Cd, Se and Ca in Tilapia. Cd can compete and interact metabolically with essential nutrients such as $\mathrm{Se}, \mathrm{Ca}, \mathrm{Zn}$, $\mathrm{Cu}$ and $\mathrm{Fe}$ in the body [16-17]. Se is important in many biochemical and physiological processes. It plays a major role in the modification of the thiol and hydroxyl groups in the Cys and Tyr. It was reported that Cd may inhibit the Se metabolism at many stages by interfering their absorption, distribution to different tissues, transport into cells and/or transport into several intracellular structures and also indirectly affecting the synthesis of various Se dependent enzymes and proteins [18-22].

Se is an essential nutrient for living organisms and is required for the synthesis of various selenoproteins (SeP). Se plays a vital role in the synthesis of a non-enzymatic antioxidant, GSH and also MT protein synthesis [23-25]. It can prevent cell damage through the activation of the antioxidant system [26-28]. Se is the most prevalent nutrient in the body and is involved in the structure and function of some enzymatic and nonenzymatic antioxidants, collectively representing all major biochemical categories and therefore is essential for normal cell function and metabolism.

Ca supplementation using the inorganic calcium chloride, protected against accumulation of $\mathrm{Cd}$ in kidney, liver and other selected tissues of fish [29]. Niyogi et al., [30] reported that water hardness has an ameliorating effect against Cd uptake and toxicity in fish. As water hardness (defined as the sum of $\mathrm{Ca}$ and magnesium (Mg) concentrations) increases acute waterborne Cd toxicity decreases [31]. The major hardness cation, Ca changes gill permeability, competes with $\mathrm{Cd}$ for binding sites on the surface of gills and reduces toxicity.

$\mathrm{Cd}$ accumulation was reduced with the increase of waterborne and dietary Ca [32-34]. Higher water Ca levels reduce the amount of $\mathrm{Cd}$ binding to gills [17] and reduce branchial $\mathrm{Cd}$ uptake rates resulting 
in lower accumulation in the kidney, liver and other tissues of fish. This approach is based on the fact that freshwater fish have two main uptake pathways for ions: the gills (waterborne ions) and the gastrointestinal tract (dietary ions) and can control the total uptake by changing the proportion of each kind of uptake according to the situation. If the fish are acquiring more ions via the gastrointestinal route, they may reduce ion uptake rates at gills thereby simultaneously reducing metal uptake via the same branchial transport pathway [29]. For example, $\mathrm{Na}$ and $\mathrm{Cu}[35]$ share the same transport pathway, and experiments showed that high dietary $\mathrm{Na}$ (as $\mathrm{NaCl}$ ) decreased gill uptake rates of both $\mathrm{Na}$ and $\mathrm{Cu}$ and reduced internal accumulation of $\mathrm{Cu}$ in rainbow trout [36]. As $\mathrm{Ca}$ and $\mathrm{Cd}$ compete for the same transport pathway, this explains why elevation of $\mathrm{Ca}$ (as $\mathrm{CaCl} 2$ ) protected against Cd accumulation in several fish tissues [37-39]. Reduced plasma Ca levels and resulting hypocalcemia after $\mathrm{Cd}$ exposure have been proposed as the fundamental mechanism of $\mathrm{Cd}$ toxicity. However, Ca-rich water may have ameliorating effect in a Ca-deficient environment where fish may be vulnerable towards Cd toxicity. Hence the present study was carried out to know whether the supplementation of Se and Ca either individually or in combination would reduce the $\mathrm{Cd}$ bioaccumulation in the selected tissues of Cd-exposed Oreochromis mossambicus.

\section{MATERIALS AND METHODS}

\section{Chemicals}

Cadmium as cadmium chloride, calcium as calcium chloride and selenium as sodium selenite were purchased from Merck (Dormstadt, Germany). All other chemicals which were used in the present study were obtained from the standard chemical companies like Sigma Chemical Co. (St Louis, Mo, USA) and SD Fine Chemicals. The chemicals used in this study were of the highest purity.

\section{Collection and exposure of animals}

Fish Oreochromis mossambicus (Tilapia) weighing $10 \pm 2$ gm were collected from the local freshwater ponds and acclimatized to laboratory conditions for a week in separate troughs. The experiment was carried out in the laboratory of Department of Zoology, Sri Venkateswara University, Tirupati. The laboratory temperature was maintained at $28 \pm 20 \mathrm{C}$. The fish were fed ad libitum with groundnut cake and water was renewed for every $24 \mathrm{~h}$ with routine changing of troughs leaving no faecal matter. The protocol and animal use has been approved by the Institutional Animal Ethics Committee (Resol. No. 10(ii)/a/CPCSCA/IAEC/SVU/AUR-JO dt 22-12-2008), Sri Venkateswara University, Tirupati, Andhra Pradesh, India.
After acclimatization fish were divided into two groups, namely control and experimental, the experimental fish have exposed to sub lethal concentration of cadmium chloride $\left(\mathrm{CdCl}_{2}\right)$ i.e., $5 \mathrm{ppm}\left(1 / 10^{\text {th }}\right.$ of $\mathrm{LC}_{50} / 48 \mathrm{~h}$ ) daily for 7,15 and $30 \mathrm{~d}(\mathrm{~d})$ time intervals. The $\mathrm{LC}_{50} / 48 \mathrm{hr}$ for $\mathrm{Cd}$ has been determined in Tilapia mossambica from our laboratory [40], and these values are once again confirmed before proceeding to the present study. Then 15d Cd-exposed fish were divided into three groups. Group-I received only Ca $(1 \mathrm{ppm})$ for 7, 15 and 30d periods. Group-II received Se supplementation (1 ppm) and Group-III was supplemented with both Ca and Se at the above said concentrations for 7,15 and $30 \mathrm{~d}$ long sojourn.

\section{Isolation of tissues}

After specific time intervals fish were sacrificed. Tissues like the liver, kidney, gill, and intestine were isolated and were immediately used for bioaccumulation studies.

\section{Bioaccumulation studies}

The Cd concentration levels in the selected tissues were measured by following the method of Kanno et al. [41]. After the specifice time intervals the test tissues like liver and kidney were isolated in ice cold conditions and then immediately they were washed with saline $(0.9 \%)$ and $50 \mathrm{mg}$ of each tissue was digested in an acid mixture of Nitric acid: Perchloric acid (3:2 V/V) for overnight. The acid mixture was then subjected to evaporation and the residue obtained was dissolved in $5 \mathrm{ml}$ double distilled water. From this $1 \mathrm{ml}$ was withdrawn and analyzed for $\mathrm{Cd}$ concentrations using Atomic Absorption Spectrophotometer (Schimadzu AA 6300). Cd concentrations were expressed as $\mu \mathrm{g} / \mathrm{gm}$ wet. weight of the tissue.

\section{Data analysis}

The data was subjected to statistical measures such as mean, standard deviation and Analysis of variance (ANOVA) using standard statistical software, SPSS (version 16). All values are expressed as mean $\pm S D$ of 6 individual samples. Significant differences were indicated at $\mathrm{P}<0.05$ level.

\section{RESULTS}

The effect of sublethal concentrations of $\mathrm{Cd}$ accumulation has been studied in different tissues like liver, kidney, gill, and intestine of freshwater edible fish Oreochromis mossambicus. Cd bioaccumulation was increased significantly with the increased period of exposure (i.e. 7, 15 and $30 \mathrm{~d}$ ) to the heavy metal $\mathrm{Cd}$ in all the test tissues (fig. 1).

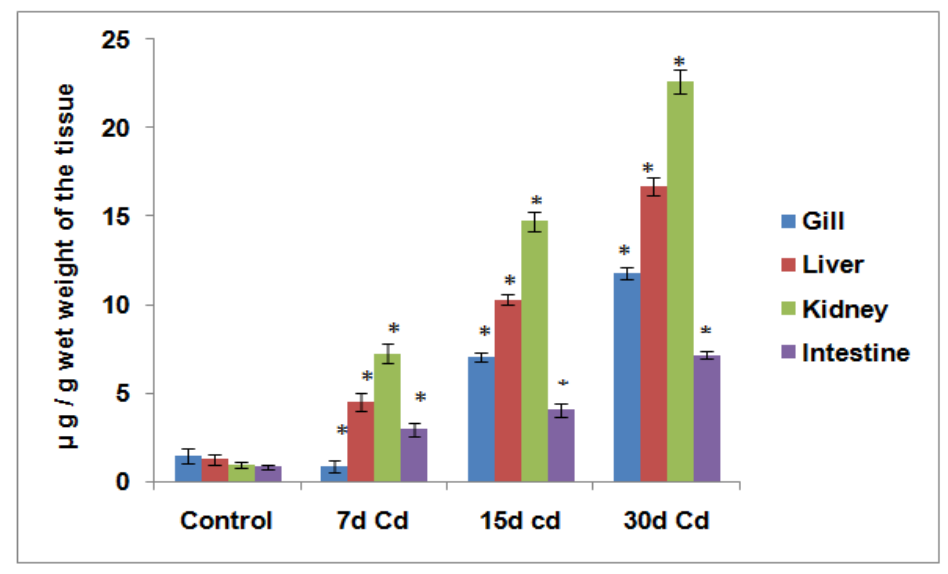

Fig. 1: Bioaccumulation ( $\mu \mathrm{g} / \mathrm{g}$ wet weight of the tissue) levels in different tissues of $O$. mossambicus exposed to Cd

\begin{abstract}
* All values are expressed as mean $\pm S D$ of 6 individual samples.
\end{abstract}
* Statistical significance was evaluated by one-way analysis of variance (ANOVA) and the Duncan's Multiple Range Test (DMRT).

* All mean values are significant at $\mathrm{P}<0.05$ level over $15 \mathrm{~d} \mathrm{Cd}$ exposure.

\section{* NS-Non significant.}

From the results, it is clear that there is a significant increase in $\mathrm{Cd}$ accumulation in the selected tissues like gill, liver, kidney, and intestine of Tilapia exposed to $\mathrm{Cd}$ at different time intervals. Among these tissues, the maximum level of $\mathrm{Cd}$ bioaccumulation was observed in $30 \mathrm{~d}$ fish kidney $(22.611 \pm 0.676 \mu \mathrm{g} / \mathrm{g}$ wet weight) indicating that the kidney is the major site of Cd accumulation. 
Further liver accumulated high $\mathrm{Cd}$ concentrations when compared to other tissues under study. Among all the selected tissues lowest concentration of $\mathrm{Cd}$ was observed in the intestine of $30 \mathrm{~d}$ exposed fish $(7.151 \pm 0.192 \mu \mathrm{g} / \mathrm{g}$ wet weight).

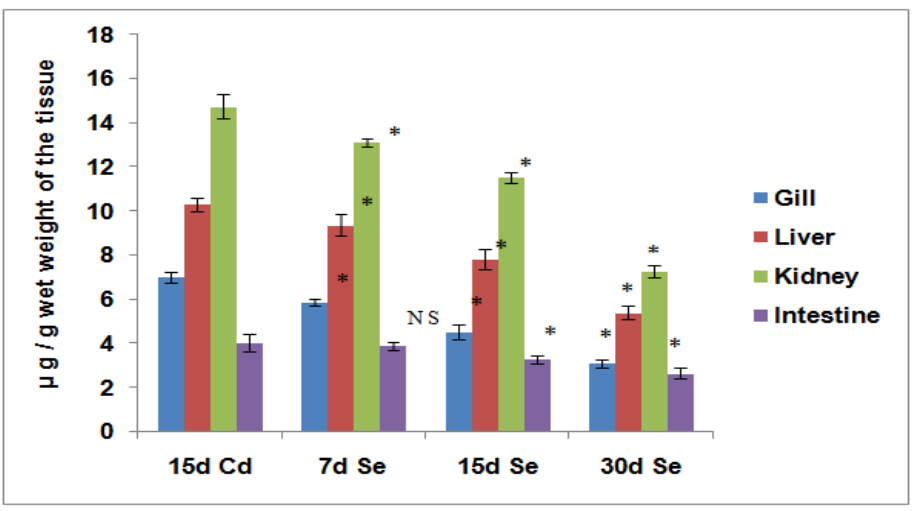

Fig. 2: Bioaccumulation ( $\mu \mathrm{g} / \mathrm{g}$ wet weight of the tissue) levels in different tissues of Cd-exposed $O$. mossambicus after supplementation with Se

* All values are expressed as mean \pm SD of 6 individual samples.

* Statistical significance was evaluated by one-way analysis of variance (ANOVA) and the Duncan's Multiple Range Test (DMRT).

* All mean values are significant at $\mathrm{P}<0.05$ level over $15 \mathrm{~d} \mathrm{Cd}$ exposure.

* NS-Non significant
When 15d Cd-exposed fish were supplemented with Se and/or $\mathrm{Ca}$ Cd concentration levels were profoundly decreased in the test tissues during all the time periods of experimentation. Maximum decrement of Cd accumulation was found in $30 \mathrm{~d}$ Ca supplemented fish gill $(2.149 \pm 0.227 \mu \mathrm{g} / \mathrm{g}$ wet weight of the tissue) than the other tissues (fig. 2). However with the combined supplementation of Se and $\mathrm{Ca}$, all the test tissues showed moderate levels of $\mathrm{Cd}$ uptake for all the time periods (fig. 4).

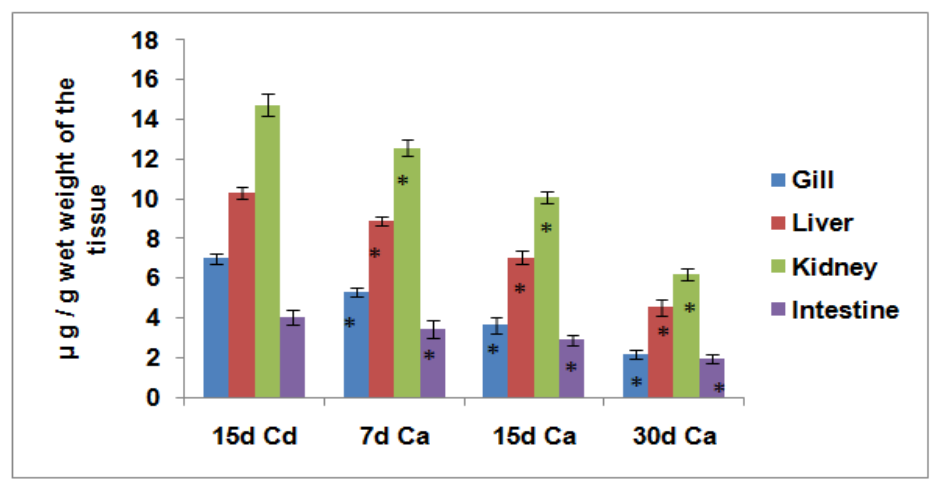

Fig. 3: Bioaccumulation ( $\mu \mathrm{g} / \mathrm{g}$ wet weight of the tissue) levels in different tissues of Cd-exposed 0 . mossambicus after supplementation with Ca

* All values are expressed as mean \pm SD of 6 individual samples.

* Statistical significance was evaluated by one-way analysis of variance (ANOVA) and the Duncan's Multiple Range Test (DMRT).
* All mean values are significant at $\mathrm{P}<0.05$ level over $15 \mathrm{~d} \mathrm{Cd}$ exposure.

* NS-Non significant

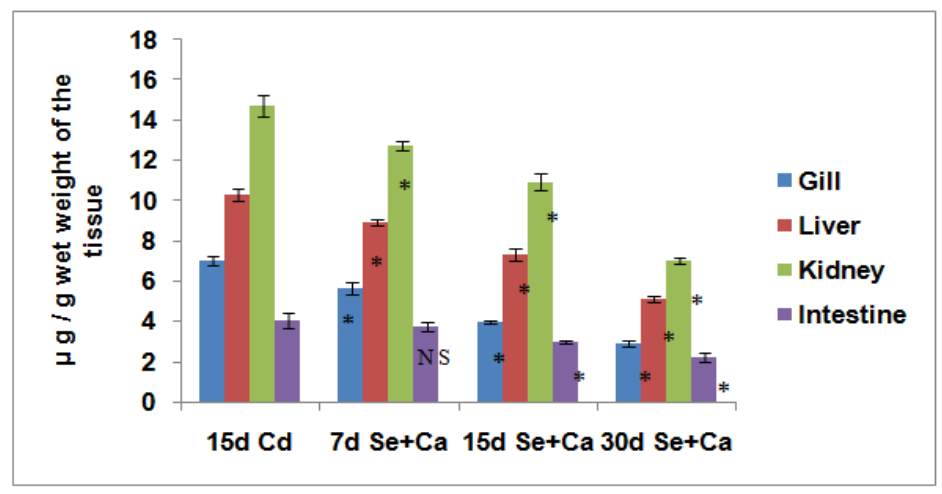

Fig. 4: Bioaccumulation ( $\mu \mathrm{g} / \mathrm{g}$ wet weight of the tissue) levels in different tissues of Cd-exposed 0 . mossambicus after supplementation with Se+Ca 
* All values are expressed as mean $\pm S D$ of 6 individual samples.

* Statistical significance was evaluated by one-way analysis of variance (ANOVA) and the Duncan's Multiple Range Test (DMRT).

* All mean values are significant at $\mathrm{P}<0.05$ level over $15 \mathrm{~d} \mathrm{Cd}$ exposure.

* NS-Non significant.

Individual Se supplementation significantly reduced the $\mathrm{Cd}$ accumulation levels in the gill, liver, kidney and intestine tissues $(3.105 \pm 0.189,5.389 \pm 0.307,7.254 \pm 0.274$ and $2.650 \pm 0.251 \mu \mathrm{g} / \mathrm{g}$ wet weight of the tissue) during only $30 \mathrm{~d}$ supplementation period (fig. 3). Hence, the low level of depletion in Cd concentration was found in the test tissues under individual supplementation of Se when compared to other modes of supplementation.

From the above results, it is clearly understood that the Ca alone as a supplement could tremendously reduce the $\mathrm{Cd}$ body burden than the other modes of supplementation in the selected tissues.

\section{DISCUSSION}

Bioaccumulation of trace metals in aquatic and terrestrial ecosystems are of special concern in the interest of human welfare. Toxic elements such as heavy metal are known to bioaccumulate in the tissues of freshwater animals like fish. A growing number of evidence has shown that several factors influence Cd accumulation in fish tissues. These factors include the environmental metal concentration and time of exposure. Several authors showed that animal tissues, contaminated in the laboratory, accumulate heavy metals in a concentration and contamination period dependent manner [42-44].

Fish have the ability to accumulate heavy metal in their tissues by the absorption along the gill surface and gut tract wall to higher levels than the toxic concentration in their environment [8]. In recent years $\mathrm{Cd}$ occupies a unique place among metals because of its diverse toxic effects: its long biological half-life (20-30 y in humans), low rate of excretion from the body $(1-2 \mu \mathrm{g} /$ day $)$ and its predominant long-term storage in soft tissues. $\mathrm{Cd}$ accumulates and proves to be very toxic in many organs, such as kidney, liver, brain, bone, blood system and lung [8]. Cd has been recognized as one of the most toxic environmental and industrial pollutant due to its ability to induce severe alterations in various organs and tissues in species of animals and humans following either acute or chronic exposure.

Several past studies investigated $\mathrm{Cd}$ accumulation and its distribution in organs $[2,13-15,45-50]$. Entry of heavy metals into the organs of a fish mainly takes place by the adsorption and absorption, and the rate of accumulation is a function of uptake and depuration rates. Reynders et al., [7] reported that on the tissue level, highest $\mathrm{Cd}$ concentrations were observed in kidneys of carp (Cyprinus carpio) and roach (Rutilus Rutilus), followed by gills, intestine, and liver. Increased $\mathrm{Cd}$ concentrations in gills and intestine probably reflected the source of metals uptake from water and food, since gills generally accumulate much higher metal concentrations than the intestine during waterborne exposure.

The Cd accumulation levels in test tissues in response to timedependent $\mathrm{Cd}$ burden were depicted in fig. 1. Data from the present study indicated that $\mathrm{Cd}$ exposure produces a significant accumulation of $\mathrm{Cd}$ in the test tissues such as gill, liver, kidney, and intestine. Similar observations are found in Persian sturgeon, Acipenser persicus reported by Zahedi et al., [44] exposed to sublethal concentration of Cd. Pollutants rarely distribute uniformly in animal body tissues, but they can accumulate to varying degrees in particular target organs, such as liver, gill or kidney. In our, study Cd has accumulated significantly in the kidney followed by liver, gill, and intestine. These results are similar to those reported by Pretto et al., [51] in Rhamdia quelen.

Our study is also proven that fish kidney and liver accumulate a higher proportion $(22.611 \pm 0.676 \mu \mathrm{g} / \mathrm{g}$ and $16.671 \pm 0.504 \mu \mathrm{g} / \mathrm{g})$ of the body burden of $\mathrm{Cd}$. The increased accumulation of $\mathrm{Cd}$ in the kidney and liver over time could be due to the involvement of these organs in the detoxification and removal of toxic substances circulating in the stream. Moreover, since these organs are the major organs of metabolic activities including detoxification of $\mathrm{Cd}[2,46$, 52]. Cd might also be transported into these organs from other tissues like the gills and intestine, for the purpose of subsequent elimination. In an attempt to detoxify Cd, liver tissue produces MT. It was assumed that Cd-MT was released from the liver cells and then gradually redistributed to the kidney, which is the main target organ for chronic Cd toxicity [53]. The kidney is thus the final destination of all the $\mathrm{Cd}$ from various tissues as it has also been shown that $\mathrm{Cd}$ MT is filtered through the glomerulus and is reabsorbed by the proximal tubular cells, possibly by endocytosis. Within these cells, the complex was taken up by lysosomes and degraded by proteases to release $\mathrm{Cd}$, which may result in renal accumulation of the metal. Thus, these factors might have accounted for the raised level of the heavy metal in the kidney during the exposure periods.

Gills were known as a temporary target organ for Cd accumulation after which the Cd is transferred to organs, such as liver, kidney, and intestine by way of the circulatory system or the enterohepatic circulation [33]. A Similar level of Cd accumulation was observed in gills when silver catfish were exposed to this metal for 7 and $14 \mathrm{~d}$. These results indicated that $\mathrm{Cd}$ accumulation occurs in the liver, kidney and gills of fish and it appears that a long period of time is required for its elimination. In the present study gill also accumulates a higher proportion of $\mathrm{Cd}(11.785 \pm 0.342 \mu \mathrm{g} / \mathrm{g})$. In the aqueous medium in which the $\mathrm{Cd}$ salt was dissolved, there were two major routes through which $\mathrm{Cd}$ can be taken up by the fish. The principle one was the oral route with subsequent intestinal absorption, while the other is the gill. Several reasons have been proposed to justify the gills as the primary site for Cd uptake, such as proximity to toxicants due to its external position, it's highly branched structural and vascular nature with the resultant highly increased surface area through which large volumes of water pass through the gill surface amongst other tissues $[8,54]$. The greater $\mathrm{Cd}$ accumulation of gills found in this study could be explained by the nonspecific binding of $\mathrm{Cd}$ ions with glycoproteins present on the gill surface, which can depress Cd uptake.

The intestine of fish accumulated the lowest level of $\mathrm{Cd}$ $(7.151 \pm 0.192 \mu \mathrm{g} / \mathrm{g})$, even after $30 \mathrm{~d}$ of exposure. During waterborne exposure of $\mathrm{Cd}$, metal levels in the digestive tract were usually low. In the case of dietary exposure of metals, their concentrations in the digestive tract increase and remain high until the end of exposure [55]. In accordance with the absence of lesions in the digestive tract well known to be impacted in fish exposed to the metal via food items, even though changes to intestine epithelia have also been found in fish exposed to increased concentrations of waterborne $\mathrm{Cd}$ with exposure period $[45,56]$.

$\mathrm{Cd}$ bioaccumulation is known to disturb the trace elements distribution in the tissues of organisms [57]. One of the most important characteristics of $\mathrm{Cd}$ toxicity was its interaction with physiologically nutrient elements [58]. Several nutrient elements like $\mathrm{Ca}, \mathrm{Se}, \mathrm{Zn}, \mathrm{Fe}$ and $\mathrm{Cu}$ participate in controlling various metabolic and signaling pathways $[15,47,59-61]$. Among these elements, Se and Ca are required for maintenance of life and health $[34,62]$. In the present study significant reduction in $\mathrm{Cd}$ bioaccumulation was observed in the selected tissues of fish supplemented with Se and/or Ca.

The interaction between Se, Ca and Cd has not been fully elucidated. However, it was believed that $\mathrm{Cd}$ competes for Se and $\mathrm{Ca}$ in several metabolic pathways and thereby reduces the levels of Se and Ca in the vital organs [63]. One of the important findings of the present study is that supplementation with Se and/or Ca significantly reduces $\mathrm{Cd}$ burden in the test tissues of Tilapia.

In our study, Se supplementation showed depletion of $\mathrm{Cd}$ accumulation in the selected tissues of Cd-exposed fish. This might be due to the depression of nonprotein sulfhydryl (-SH) groups in fish tissues. It suggests that Se protects cells from toxic effects of $\mathrm{Cd}$ by maintaining the availability of antioxidant non protein-SH groups and further because of Cd affinity towards-SH groups may in turn reduce free $\mathrm{Cd}$ level in test tissues, thus attenuating the toxic effect of Cd. Tawwab and Wafeek [64] reported that Se prevents acute Cd toxicity through a mechanism that does involve the induction of metallothionein. In the present study, the bioavailability of Se 
increases with the supplementation, which inturn is responsible in reducing the Cd body burden. The principle role of Se is associated with the control of LPO, because Se was a component of selenoenzymes contributing to the antioxidant system. Recently Cogun et al., [65] also reported the protective effect of Se against heavy metal $\mathrm{Hg}$ toxicity in Oreochromis niloticus. Lazarus et al., [23] also evaluated the influence of Se on Cd retention in suckling rats. Results of the present study revealed a significant decrease in Cd body burden in fish supplemented with Se, which was in agreement with earlier studies on zebrafish, Danio rerio exposed to Cd [66]. Hence, the bioavailability of Se might be helpful in the reduction of Cd accumulation.

$\mathrm{Ca}$ is an important element needed for the maintenance of membrane integrity and ion regulation. Cd can damage gills and decreases the activity of gill Ca-ATPase, which leads to fish hypocalcaemia and can result in skeletal deformities and disturbance in Ca balance [33]. The most sensitive cellular targets of $\mathrm{Cd}$ seem to be ion transport and signal transduction. These include intracellular mobilization of second messenger's inositol triphosphate and $\mathrm{Ca}$, inhibition of plasma membrane $\mathrm{Ca}$ channels and inhibition of Ca-ATP ases of the sarcoplasmic reticulum [67].

The present study revealed interesting interactions between $\mathrm{Ca}$ supplementation and the response to Cd exposure. Among all the exposure periods, $30 \mathrm{~d}$ Ca supplementation showed a reduction in tissue $\mathrm{Cd}$ accumulation. It was clear from the present study that the toxicity of metal was affected by $\mathrm{Ca}$ which in turn reduces the toxic effect of metal through competitive inhibition at the gill surface. The nontoxic Ca competes with the toxic metals for the same binding sites $[15,29,68]$. Baldisserotto et al., [29] also demonstrated that trout fed for $7 \mathrm{~d}$ with $60 \mathrm{mg} / \mathrm{g}$ Ca showed reductions in waterborne Cd uptake comparable with the present study.

The efficiency of Ca supplementation in reducing waterborne $\mathrm{Cd}$ accumulation was highest at the site of uptake, the gill and this lead to a lower accumulation of $\mathrm{Cd}$ in internal tissues. Upon uptake from the water, Cd like other metals bind to transport proteins in the plasma and was distributed via the arterial system to internal organs, where it may be stored or excreted [69]. Increased Ca levels in the medium resulted in a slower transfer of $\mathrm{Cd}$ from the gills to the blood and the rate of $\mathrm{Cd}$ accumulation was lowered in the liver, kidney and other selected tissues. Similar findings were reported in rainbow trout by Hollis et al., [70] and in Cirrhina mrigala by Ghosh and Adhikari [71]. In the absence of elevated $\mathrm{Ca}$, test tissues accumulated Cd continuously over the duration of the experiment.

\section{CONCLUSION}

It could be therefore concluded that either Se and/or $\mathrm{Ca}$ supplementation might play a vital role in reducing the $\mathrm{Cd}$ tissue burden of freshwater fish. However, Ca alone supplementation has a pronounced effect in depleting Cd concentrations when compared to other modes of supplementation, thereby mitigating the risk of potential hazards to human health. Such dietary manipulations may further provide the best defense against environmental exposures to heavy metals and needs more attention.

\section{AUTHORS CONTRIBUTIONS}

All the author have contributed equally

\section{CONFLICT OF INTERESTS}

Declared none

\section{REFERENCES}

1. Saxena R, Garg P. Vitamin E provides protection against in vitro oxidative stress due to pesticide (Chlorphrifos and Endosulfan) in goat RBC GERF. Bull Biosci 2010;1:1-6.

2. Cirillo T, Amodio Cocchieri R, Fasano A, Lucisano A, Tafuri S, Ferrante E, et al. Cadmium accumulation and antioxidant responses in Sparus aurata exposed to waterborne cadmium. Arch Environ Contam Toxicol 2012;62:118-26.

3. Quinaia SP, Rollemberg MCE, Da Silva JBB. On-line preconcentration system using a mini-column of activated carbon for cadmium and lead determination in water by flame atomic absorption spectrometry. Canadian J Animal Sci 2006;51:225-33.

4. Mekkawy IAA, Mahmoud UM, Wassif ET, Naguib M. Effects of cadmium on some haematological and biochemical characteristics of Oreochromis niloticus (Linnaeus, 1758) dietary supplemented with tomato paste and vitamin E. Fish Physiol Biochem 2011;37:71-84.

5. Mekkawy IAA, Lashein FE. The effect of lead and cadmium on LDH and G-6-PDH isozyme patterns exhibited during the early embryonic development of the teleost fish, ctenopharyngodon idellus with emphasis on the corresponding morphological variations. In: The Big Fish Bang: Proceedings of the $26^{\text {th }}$ annual larval fish conference (LFC2002); 2002. HI Browman, Skiftesvik AB. Bergen, Norway; 2003. p. 275-92.

6. Yilmaz AB. Comparison on heavy metal levels of grey mullet (Mugil cephalus L.) and sea beam (Sparus aurata L.) caught in Iskenderum Bay (Turkey). Turkey J Vet Anim Sci 2005;29:25762.

7. Reynders H, Bervoets L, Gelders M, De Coen WM, Blust R. Accumulation and effects of metals in caged carp and resident roach along a metal pollution gradient. Sci Total Environ 2008;391:82-95.

8. Annabi A, khaled Said K, Messaoudi I. Cadmium: bioaccumulation, histopathology and detoxifying mechanisms in fish. Am J Res Communication 2013;1:60-79.

9. Soeginato A. Bioaccumulation of heavy metals in some commercial animals caught from selected coastal waters of East Java, Indonesia. Res J Agric Biol Sci 2008;4:881-5.

10. Ibrahim S, Said HA. Heavy metals load in tilapia species: a case study of Jakara river and Kusalla dam, Kano state, Nigeria. Bayero J Pure Appl Sci 2010;3:87-90.

11. Vasantharaja D, Ramalingam V. Neurotoxic effect of titanium dioxide nanoparticles: biochemical and pathological approach in male wistar rats. Int J Appl Pharm 2018;10:74-81.

12. Lalitha Devi B, Muthiah NS, Satya Narayana Murty K. Antioxidant activity of conjugated linoleic acid. Asian J Pharm Clin Res 2018;11:169-73.

13. Obaiah Jamakala, Usha Rani A. Protective role of trace elements against cadmium-induced alterations in the selected oxidative stress enzymes in liver and kidney of fresh water teleost, Oreochromis mossambicus (Tilapia). Int J Pharm Pharm Sci 2012;4 Suppl 5:303-10.

14. Obaiah Jamakala, Usha Rani A. Calcium impact on cadmium induced alterations in selected oxidative stress enzymes in the fresh water teleost, Oreochromis mossambicus (Tilapia). Golden Res Thoughts 2013;3:1-6.

15. Obaiah Jamakala, Usha Rani A. Zinc and calcium supplementation to combat cadmium-induced bioaccumulation in selected tissues of fresh water teleost, Oreochromis mossambicus (Tilapia). Int J Universal Pharm Biosci 2014;3:229-42.

16. Ilback NG, Lindh U, Minqin R, Friman G, Watt F. Selenium and mercury are redistributed to the brain during viral infection in mice. Biol Trace Elem Res 2005;108:215-24.

17. Liu CT, Chou MY, Lin CH, Wu SM. Effects of ambient cadmium with calcium on mRNA expressions of calcium uptake related transporters in zebra fish (Danio rerio) larvae. Fish Physiol Biochem 2012;38:977-88.

18. Włodarczyk M, Minta B, Biernacki J, Szkoda Żmudzki J. Selenium protection against cadmium toxicity in hamster embryos. Polish J Environ Studies 2000;9:323-7.

19. Bansal MP, Kaur P. Selenium, a versatile trace element: current research implications. Indian J Exp Biol 2005;43:1119-29.

20. El-Sharaky AS, Newairy AA, Badreldeen MM, Ewedaa SM, Sheweita SA. Protective role of selenium against renal toxicity induced by cadmium in rats. Toxicology 2007;235:185-93.

21. Shilo S, Pardo M, Aharoni Simon M, Glibter S, Tirosh 0. Selenium supplementation increases liver MnSOD expression: a molecular mechanism for hepato-protection. J Inorg Biochem 2008;102:110-8.

22. Chen X, Zhu YH, Cheng XY, Zhang ZW, Xu SW. The protection of selenium against cadmium-induced cytotoxicity via the heat shock protein pathway in chicken splenic lymphocytes. Molecules 2012;17:14565-72. 
23. Lazarus M, Orct T, Jurasoviæ J, Blanusa M. The effect of dietary selenium supplementation on cadmium absorption and retention in suckling rats. Biometals 2009;22:973-83.

24. Patra RC, Rautray AK, Swarup D. Oxidative stress in lead and cadmium toxicity and its amelioration. Vet Med Int 2011. Doi:10.4061/2011/457327.

25. Zwolak I, Zaporowska H. Selenium interactions and toxicity: a review. Cell Biol Toxicol 2012;28:31-46.

26. Hassan W, Ibrahim M, Nogueira C, Ahmed M, Rocha J. Effects of acidosis and $\mathrm{Fe}(\mathrm{II})$ on lipid peroxidation in phospholipid extract: comparative effect of diphenyl diselenide and ebselen. Environ Toxicol Pharmacol 2009;28:152-4.

27. Machado Mda S, Villela IV, Moura DJ, Rosa RM, Salvador M, Lopes NP, et al. 3'3-ditriXuoromethyldiphenyl diselenide: a new organoselenium compound with interesting antigenotoxic and antimutagenic activities. Mut Res 2009;673:133-40.

28. Valdiglesias V, Pasaro E, Mendez JW, LaVon B. In vitro evaluation of selenium genotoxic, cytotoxic, and protective effects: a review. Arch Toxicol 2010;84:337-51.

29. Baldisserotto B, Kamunde C, Matsuo A, Wood C. A protective effect of dietary calcium against acute waterborne cadmium uptake in rainbow trout. Aquat Toxicol 2004;67:57-73.

30. Niyogi S, Kent K, Wood CM. Effects of water chemistry variables on gill binding and acute toxicity of cadmium in rainbow trout (Oncorhynchus mykiss): a biotic ligand model (BLM) approach. Comp Biochem Physiol Part C: Toxicol Pharmacol 2008;148:305-14.

31. Brinkman SF, Hansen DL. Toxicity of cadmium to early life stages of brown trout (Salmo trutta) at multiple water hardnesses. Environ Toxicol Chem 2007;26:1666-71.

32. Hansen JA, Welsh PG, Lipton J, Cacela D, Dailey AD. Relative sensitivity of bull trout (Salvelinus confluentus) and rainbow trout (Oncorhynchus mykiss) to acute exposures of cadmium and zinc. Environ Toxicol Chem 2002;21:67-75.

33. Wu SM, Ho YC, Shih MJ. Effects of $\mathrm{Ca}^{2+} \mathrm{Or} \mathrm{Na}^{+}$on metallothionein expression in tilapia larvae (Oreochromis mossambicus) exposed to cadmium or copper. Arch Environ Contam Toxicol 2007;52:229-34.

34. Ng TYT, Klink JS, Wood CM. Does dietary Ca protect against toxicity of a low dietborne Cd exposure to the rainbow trout? Aquat Toxicol 2009;91:75-86.

35. Grosel M, Wood CM. Copper uptake across rainbow trout gills: mechanisms of apical entry. J Exp Biol 2002;205:1179-88.

36. Kamunde CN, Pyle GG, McDonald DG, Wood CM. Influence of dietary sodium and waterborne copper exposure toxicity and gill copper binding in rainbow trout, Oncorhynchus mykiss. Environ Toxicol Chem 2003;22:342-50.

37. Zohouri MA, Pyle GG, Wood CM. Dietary Ca inhibits waterborne Cd uptake in Cd-exposed rainbow trout, Oncorhynchus mykiss. Comp Biochem Physiol 2001;130C:347-56.

38. Ojo AA, Wood CM. In vitro characterization of cadmium and zinc uptake via the gastro-intestinal tract of the rainbow trout (Oncorhynchus mykiss): effective interactive effects and the influence of calcium. Aquatic Toxicol 2008;89:55-64

39. Kwong RWM, Niyogi S. The interactions of iron with other divalent metals in the intestinal tract of a fresh water teleost, rainbow trout (Oncorhynchus mykis). Comp Biochem Physiol C 2009;150:442-9.

40. Usha Rani A, Ramamurthi R. Effect of sublethal concentration of cadmium on oxidative metabolism in the fresh water teleost Tilapia mossambica. Indian J Comp Anim Physiol 1987;5:71-4.

41. Kanno S, Aoki Y, Suzuki JS, Takeichi N, Misawa S, Suzuki KT. Enhanced synthesis of metallothionein as a possible cause of abnormal copper accumulation in LEC rats. J Inorg Biochem 1994;56:117-25.

42. Francis PC, Birge WJ, Black JA. Effects of cadmium enriched sediment on fish and amphibian embryorval stages. Fish Physiol Biochem 2004;36:403-9.

43. Kamunde C. Early subcellular partitioning of cadmium in the gill and liver of rainbow trout (Oncorhynchus mykiss) following low-to-near-lethal waterborne cadmium exposure. Aquat Toxicol 2009;91:291-301.

44. Zahedi S, Mirvaghefi A, Rafati M, Mehrpoosh M. Cadmium accumulation and biochemical parameters in juvenile persian sturgeon, Acipenser persicus, upon sublethal cadmium exposure. Comp Clin Pathol 2013;22:805-13.

45. Isani G, Andreani G, Cocchioni F, Fedeli D, Carpene E, Falcioni G. Cadmium accumulation and biochemical responses in Sparus aurata following sub-lethal Cd exposure. Ecotoxicol Environ Safe 2009;72:224-30.

46. Creti P, Trinchella F, Scudiero R. Heavy metal bioaccumulation and metallothionein content in tissues of the sea bream Sparus aurata from three different fish farming systems. Environ Monit Assess 2010;165:321-9.

47. Obaiah Jamakala, Bhavani G, Usha Rani A. Effect of calcium on cadmium induced bioaccumulation in selected tissues of fresh water teleost, Oreochromis mossambicus (Tilapia). Indian Streams Res J 2013;3:56-9.

48. Obaiah Jamakala, Usha Rani A. Metallothioneins role against cadmium toxicity in zinc and calcium supplemented Oreochromis mossambicus (Tilapia). Int J Pharma Bio Sci 2015;6:149-63.

49. Obaiah Jamakala, Usha Rani A. Zinc and calcium supplementation to combat cadmium induced bioaccumulation in fresh water teleost Oreochromis mossambicus (Tilapia). Int J Pharm Pharm Sci 2016;8:186-90.

50. Obaiah Jamakala, Usha Rani A. Possible detoxification role of zinc and selenium supplementation against cadmium induced bioaccumulation and oxidative stress in teleostean fish Oreochromis mossambicus. Eur J Pharm Med Res 2017;4:370-82.

51. Pretto A, Loro VL, Baldisserotto B, Pavanato MA, Moraes BS, Menezes C, et al. Effects of water cadmium concentrations on bioaccumulation and various oxidative stress parameters in Rhamdia quelen. Arch Environ Contam Toxicol 2011;60:309-18.

52. Klaassen CD, Liu J, Diwan BA. Metallothionein protection of cadmium toxicity. Toxicol Appl Pharmacol 2009;238:215-20.

53. WHO. Environmental health criteria, 134, cadmium. World Health Organization, Geneva; 1992.

54. Jayakumar P, Paul VI. Patterns of cadmium accumulation in selected tissues of the catfish Clarias batracus (Linn.) exposed to sublethal concentration of cadmium chloride. Vet Arch 2006; 76:167-77.

55. Jezierska B, Witeska M. The metal uptake and accumulation in fish living in polluted waters. Soil and Water Pollution Monitoring, Protection and Remediation; 2006. p. 107-14.

56. Giari L, Manera M, Simoni E, Dezfuli BS. Cellular alterations in different organs of European sea bass Dicentrarchus labrax (L.) exposed to cadmium. Chemosphere 2007;67:1171-81.

57. Turgut $\mathrm{S}$, Polat $\mathrm{A}$, Inan $\mathrm{M}$, Turgut G, Emmungil G, Bican $\mathrm{M}$, et al. Interaction between anemia and blood levels of iron, zinc, copper, cadmium, and lead in children. Indian J Pediatrics 2007;74:827-30.

58. Renata SK, Izabela H. Cadmium, zinc and iron interactions in the tissues of bank vole Clethrionomys glareolus after exposure to low and high doses of cadmium chloride. Biometals 2007;20:743-9.

59. Peraza MA, Ayala Fierro F, Barber DS, Casarez E, Rael LT. Effects of micronutrients o $\mathrm{n}$ metal toxicity. Environ Health Perspect 1998;106:203-16.

60. Flora SJS, Mittal M, Mehta A. Heavy metal induced oxidative stress and its possible reversal by chelation therapy. Indian J Med Res 2008;128:501-23.

61. Asagba SO. Role of diet in absorption and toxicity of oral cadmiumA review of the literature. Afr J Biotechnol 2009;8:7428-36.

62. Talas ZS, Orun I, Ozdemir I, Erdogan K, Alkan A, Yilmaz I. Antioxidative role of selenium against the toxic effect of heavy metals $\left(\mathrm{Cd}^{+2}, \mathrm{Cr}^{+3}\right)$ on the liver of rainbow trout (Oncorhynchus mykiss walbaum 1792). Fish Physiol Biochem 2008;34:217-22.

63. Gailer J. Chronic toxicity of AsIII in mammals: the role of (GS) 2AsSe-. Biochimie 2009;91:1268-72.

64. Tawwab MA, Wafeek M. Response of nile tilapia, Oreochromis niloticus (L.) to environmental cadmium toxicity during organic selenium supplementation. $8^{\text {th }}$ International Symposium on Tilapia in Aquaculture; 2008. p. 415-30.

65. Cogun HY, Ozgur Firat, Ozge Firat, Yuzereroglu TA, Gok G, Kargin F, et al. Protective effect of selenium against mercury-induced toxicity on hematological and biochemical parameters of Oreochromis niloticus. J Biochem Mol Toxicol 2012;26:117-22. 
66. Banni M, Chouchene L, Said K, Kerkeni A, Messaoudi I. Mechanisms underlying the protective effect of zinc and selenium against cadmium induced oxidative stress in zebra fish Danio rerio. Biometals 2011;24:981-92.

67. Flora SJS. Metal poisoning: threat and management. Al Ameen J Med Sci 2009;2:4-26.

68. Krishnammal S, Navaraj PS. A dietary chemical study of the protection of calcium against cadmium uptake in freshwater fish. IOSR J Pharm Biol Sci 2012;3:19-26.
69. Franklin NM, Glover CN, Nicol JA, Wood CM. Calcium/cadmium interactions at uptake surfaces in rainbow trout: waterborne versus dietary routes of exposure. Environ Toxicol Chem 2005;24:2954-64

70. Hollis L, McGeer JC, McDonald DG, Wood CM. Protective effects of calcium against chronic waterborne cadmium exposure to juvenile rainbow trout. Environ Toxicol Chem 2000;19:2725-34.

71. Ghosh L, Adhikari S. Accumulation of heavy metals in fresh water fish-an assessment of toxic interactions with calcium. Am J Food Technol 2006;1:139-48. 